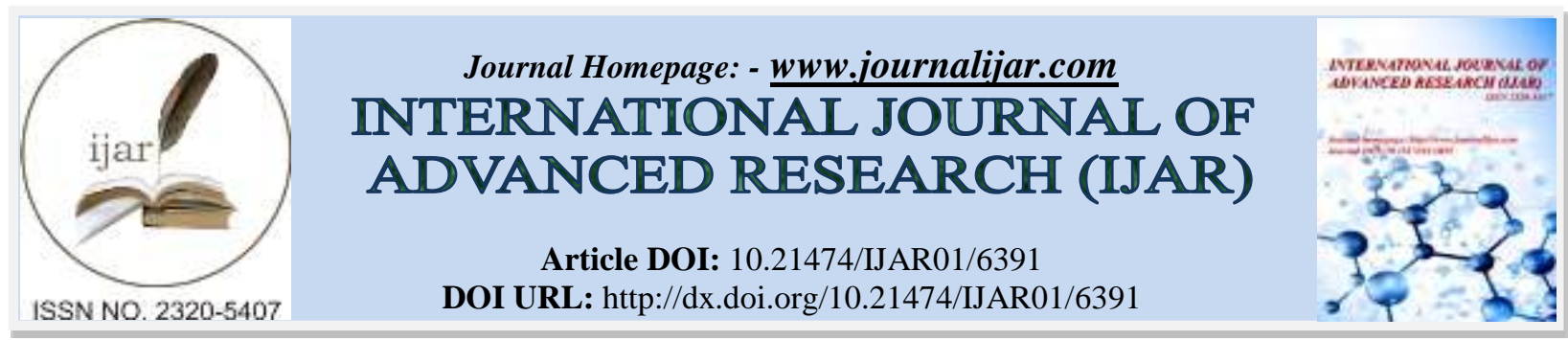

RESEARCH ARTICLE

\title{
GERMINATION SEEDS FROM POWDER BIO ATTEMPTS OF THREE PLANTS KHAYA SENEGALENSIS, EUCALYPTUS CAMALDULENSIS, AZADIRACHTA INDICA FOR THE PROTECTION AGAINST OF GROUNDNUT WEEVILS CARYEDON SERRATUS OL.
}

1. University of Thies (ED 2DS)

2. Department of vegetal Biology, Faculty of Sciences and Technics, University Cheikh Anta DIOP of Dakar, BP 5005, Senegal.

\section{Manuscript Info}

(.........................

Manuscript History

Received: 23 November 2017

Final Accepted: 25 December 2017

Published: January 2018

Key words:-

plants, vegetable powders (Khaya, Eucalyptus, Azadirachta), germination, seeds.

\section{Abstract}

The seeds treated to different products (Khaya senegalensis, Eucalyptus camaldulensis and Azadirachta indica) during bio-attempts of stocking present variations in germination percentage according to the biocide product for the test of Student-Newman-Keuls at the beginning of 5\%. In considering one or different plant(s) and the types of vegetable powders, the non-treated indicators peanut ArNT $(0 \mathrm{~g}),(98.33 \% \pm 0.88)$ and chemical of reference $\mathrm{P}(0.5 \mathrm{~g}),(90.66 \% \pm 1,00)$ are meaningfully different between them and are meaningfully different from powder formulations according to doses. Even if meaningful differences are detected, the results of the germination tests show rates higher than $75 \%$ which prove a good protection of seeds by the vegetable powders without affecting their germination power. However alternatives of bioattempts in presence of substance indicators inert in real environment could be envisaged in order to see the viability of treated seeds and this in a long-preservation period.

Copy Right, IJAR, 2018,. All rights reserved.

\section{Introduction:-}

The viability of seeds is the measure of the seeds number in a group of seeds that are alive and can grow in plants that will develop in the appropriate conditions in the fields (Rao et al., 2006). To germinate, the seed should but submitted to favourable external conditions (water, light, temperature, oxygen) and internal (absence of inhibition and dormancy, maturity, aptitude to germinate) (Larpent, 1976; Singh and Rathod, 2002; Rao et al., 2006). The germination test is realized to determine which proportion of seeds after stocking will germinate in favorable conditions and will produce normal seedlings capable of developing mature plants for their reproduction (Rao et al., 2006). In this fact, there are many tests the most used of which are the bio-chemical and germination tests. The groundnut germination is aboveground. The reservations in the cotyledons dwindle as they ensure the vigorous growth to the seedlings. The pivoting root is in general well developed and the secondary roots bear nodosities containing nitrogen fixative bacteria (Diaw, 1999).

During this activity we are going to lead observations as for the germination tests of groudnut seeds. We will put the germinative faculty in an obvious place that is to say the percentage of seeds likely to produce within a given time healthy and viable seedlings, $75 \%$ is generally an acceptable rate. 


\section{Methodology:-}

Seeds from different treatments Khaya senegalensis, Eucalyptus camaldulensis and Azadirachta indica are used for the germination test. Circular molded boxes $(\mathrm{D}=15 \mathrm{~cm})$ are used for this operation. We put at the bottom of the molded box a blotting paper which enables to keep the water in order to maintain a moistening degree of seeds that are enough to the germination of these ones. Besides, it enables to limit the water access to the contact of the seed which would lead to its deterioration. After the mixture of seeds from different treatments, a number of 100 seeds taken at random is introduced in each box. The total number of seeds used during the germination bio attempts is about 3300 seeds. Then we cover up the seeds again with another blotting paper after moistening in water. All is then closed by a glass cover; the seedbed date, the treatment and the code of the repetition are marked on the box covering. Three repetitions are set by treatment. The observations are made every 24 hours during 72 hours ( 3 days). Within $72 \mathrm{~h}$ (3days), the percentage of germinated seeds is taken at the same time with the qualitative observations with an observation form. Are considered as germinated seeds, those whose radicle is pierced the integument and whose length is more than $2 \mathrm{~mm}$.

\section{Survey materials:-}

During the experience, the used materials are: the petri dishes, paper serving of support in the bottom of dishes, glue, scissors, distilled water, labelling to indicate the petri dishes, trickles for the water imbibition of groundnut seeds.

\section{Experimental mechanism:-}

The experimental mechanism is conceived according a complete randomization and the labelling of petri dishes that should contain the seeds is realized under a coded form in accordance with a total randomization. The used vegetable material is the groundnut from the different treatments. An experimental unit represents a petri dish containing a number of groundnut seeds. For each treatment of (Khaya senegalensis, Eucalyptus camaldulensis, Azadirachta indica), we have 3 doses, a chemical reference witness called Percal $1 \%(\mathrm{P})$ and a White Witness untreated peanut (Ar NT).

\section{OUTCOMES}

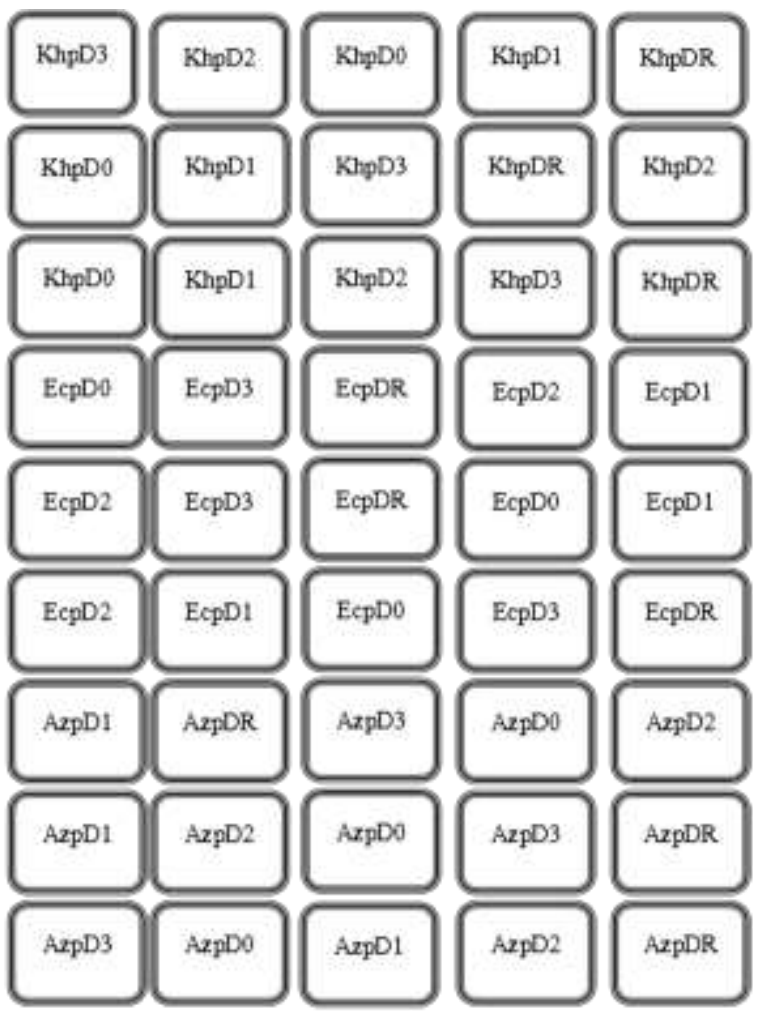

Schema experimental of biocides effects

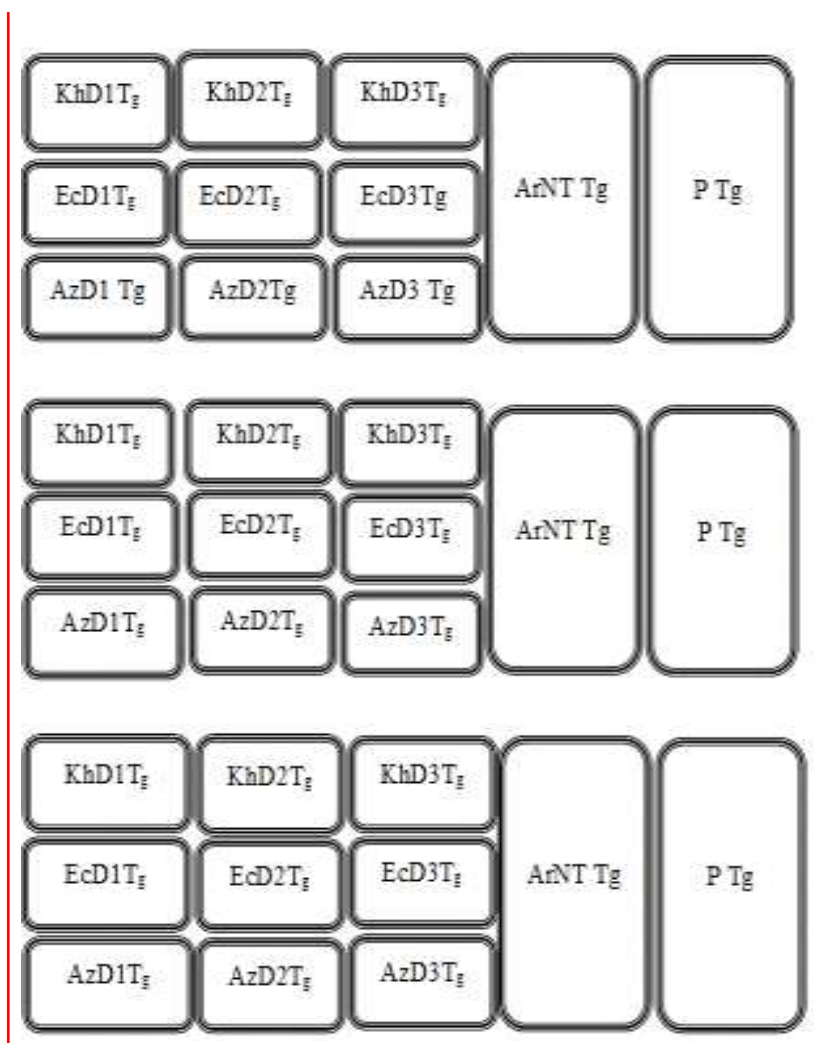

Schema experimental of germination seeds 


\section{Results:-}

Germination of seeds from the treatment Khaya senegalensis' powder

The observation of statistical analysis outcomes on the bio-trials of germination shows that Khaya vegetable powder treatment offers in the whole percentages of higher germination and this one whatever is the dose. We can register $\mathrm{KhD} 1(24 \mathrm{~g} \mathrm{p} / 120 \mathrm{~g} \mathrm{gr}), \mathrm{KhD} 2(30 \mathrm{~g} \mathrm{p} / 120 \mathrm{~g}$ gr) and KhD3 (40g p/120g gr) respectively (79.33\%), (85\%), (90\%). For the witnesses ArNT $(0 \mathrm{~g} \mathrm{p} / 120 \mathrm{~g}$ gr) and P $(0.5 \mathrm{~g} \mathrm{p} / 120 \mathrm{~g}$ gr) of respective averages des percentages of $(98.33 \%)$ and $(90.66 \%)$.

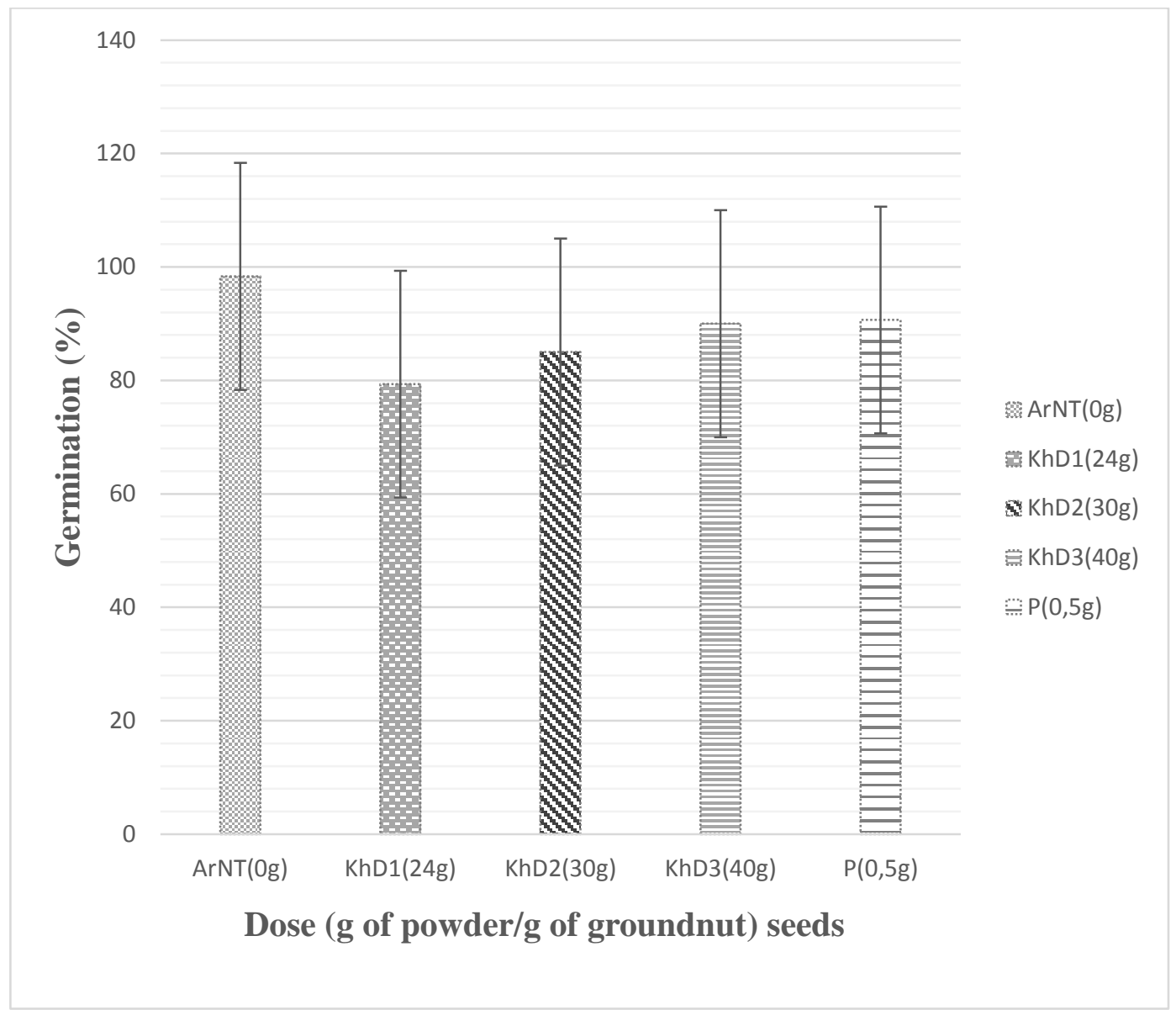

Figure 1:- Germination of seeds from the treatment Khaya senegalensis' powder

Germination of seeds from the treatment Eucalyptus camaldulensis' powder:-

The outcomes got from the bio-attempts with the Eucalyptus vegetable powder treatment allows to register with EcD3 (40g p/120g gr) the germination percentage the highest (88.33\%) followed with EcD2 (30g p/120g gr) (85\%) whereas EcD1 $(24 \mathrm{~g} \mathrm{p} / 120 \mathrm{~g} \mathrm{gr})$ register only $(81 \%)$. For the witnesses ArNT $(0 \mathrm{~g})$ and $\mathrm{P}(0.5 \mathrm{~g})$ of respective averages percentages of $(98.33 \%)$ and $(90.66 \%)$. 


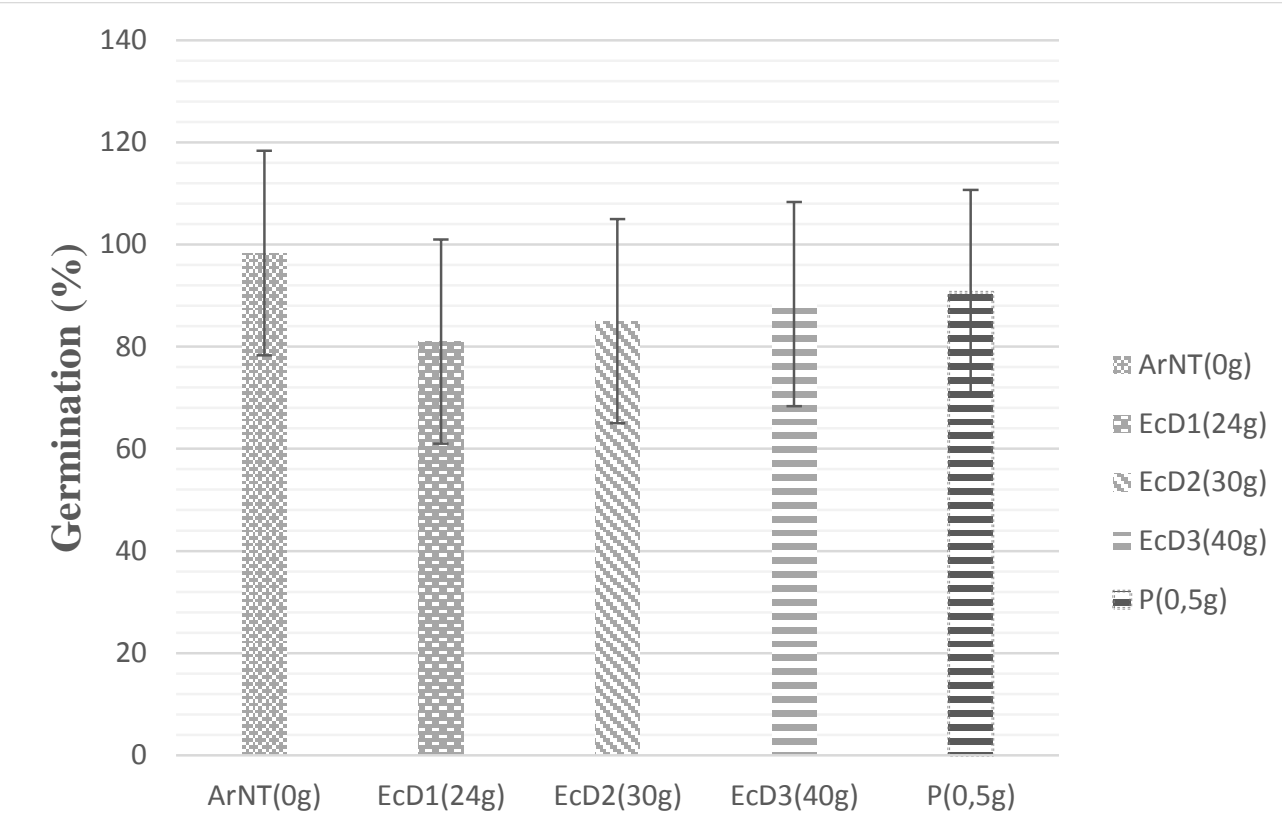

Dose (g of powder/g of groundnut) seeds

Figure 2:- Germination of seeds from the treatment Eucalyptus camaldulensis' powder

\section{Germination of seeds from treatment Azadirachta indica's powder}

The outcomes obtained during the bio-trials let show percentages of germination which decrease weakly in relation to the powder treatments (Khaya senegalensis, Eucalyptus camaldulensis) and this one whatever the considered powder dose is. We can register with AzD1 (24g p/120g gr) (79.66\%), AzD2 (30g p/120g gr) (80.33\%), AzD3 (40g $\mathrm{p} / 120 \mathrm{~g}$ gr $)(81 \%)$. For the witnesses ArNT $(0 \mathrm{~g} \mathrm{p} / 120 \mathrm{~g}$ gr) and P $(0.5 \mathrm{~g} \mathrm{p} / 120 \mathrm{~g}$ gr) of respective averages percentages of $(98.33 \%)$ and $(90.66 \%)$.

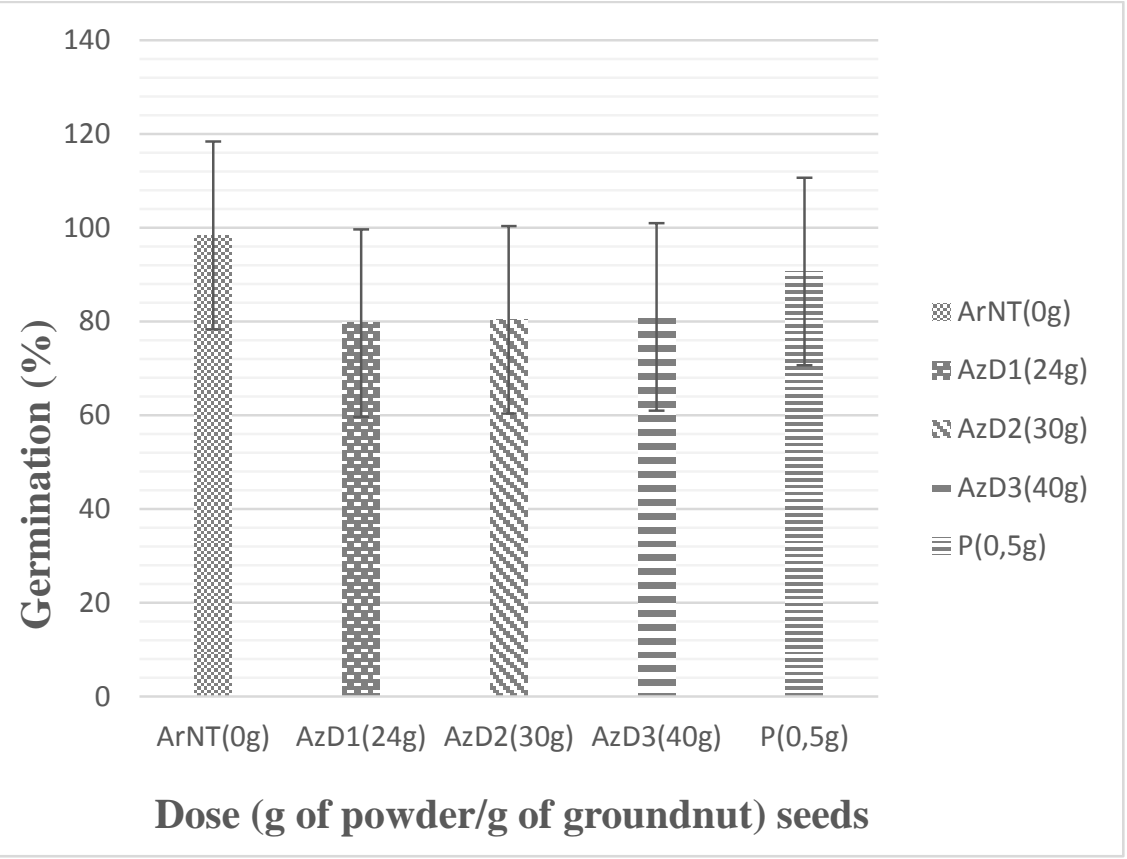

Figure 3:- Germination of seeds from the treatment Azadirachta indica's powder 
Compared effects of the germination average percentages for each type of vegetable power (Khaya senegalensis; Eucalyptus camaldulensis, Azadirachta indica) according to the doses D1, D2 and D3.

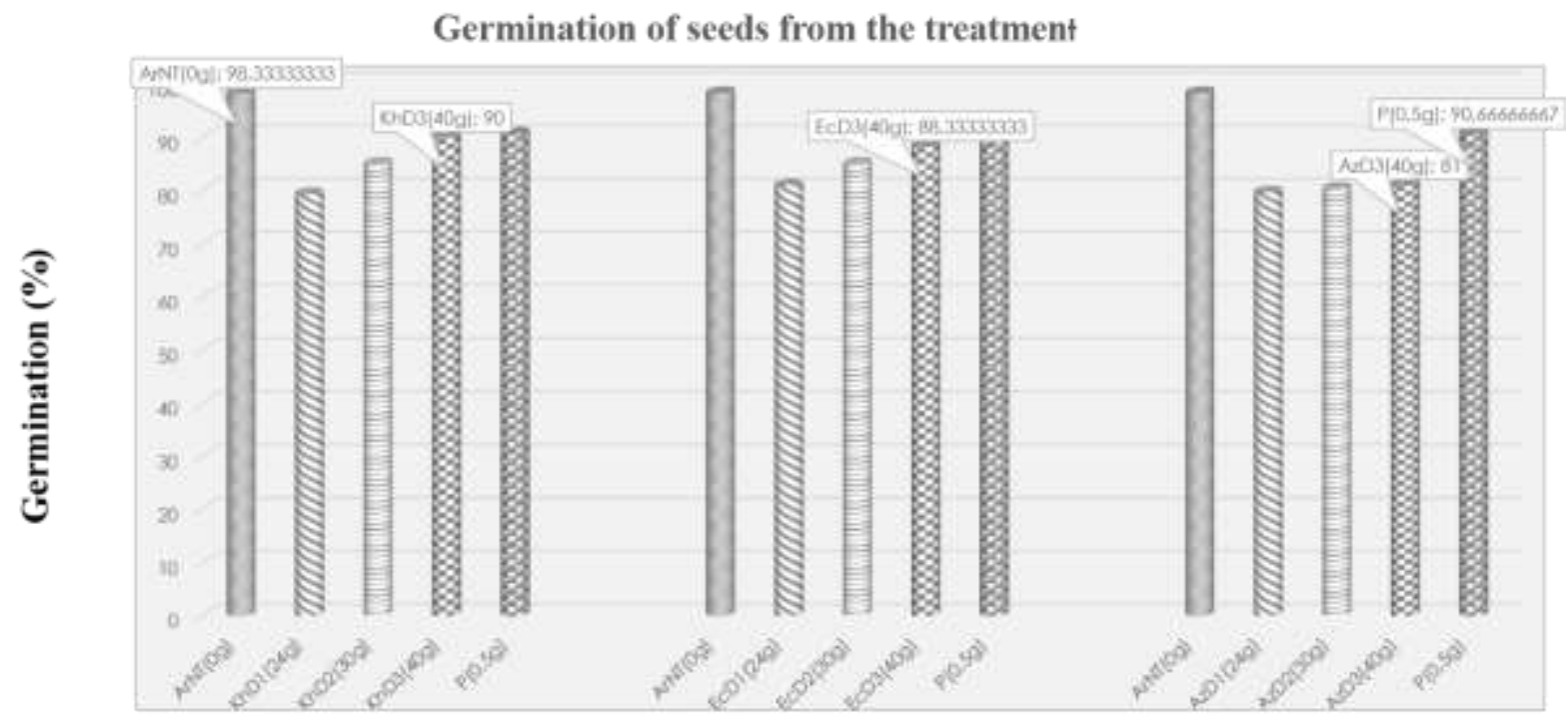

\section{Dose (g of powder/g of groundnut) seeds}

Figure 4:- Germination rates (average \pm standard error) of infested seeds by treated weevils with the three plants vegetable powders in presence of the witnesses TB and Percal $1 \%$ after 8 exhibition days in the ambient conditions of laboratory $\left(\mathrm{t} \approx 34.21 \pm 1{ }^{\circ} \mathrm{C} ; \mathrm{HR} \approx 46.01 \pm 3 \%\right)$

Compared effects of the germination average percentages for each type of the vegetable powder (Khaya senegalensis, Eucalyptus camaldulensis, Azadirachta indica) according to the doses D1, D2 and D3.

Table 1:- Compared germination of seeds from a vegetable powder type

\begin{tabular}{|c|c|c|}
\hline \multirow{2}{*}{$\begin{array}{l}\text { Vegetable powders/ } \\
\text { Witnesses }\end{array}$} & \multirow[t]{2}{*}{ Doses $(\mathrm{g})$} & LT50 \\
\hline & & C. serratus Larva \\
\hline \multirow{5}{*}{$\begin{array}{l}\text { Khaya } \\
\text { senegalensis }\end{array}$} & ArNT $(0 g)$ & $98,33^{\mathrm{a}} \pm 0,88$ \\
\hline & KhD1 (24g) & $79,33^{\mathrm{d}} \pm 0,12$ \\
\hline & KhD2 (30g) & $85^{\mathbf{c}} \pm 0,23$ \\
\hline & KhD3 (40g) & $90^{\mathbf{c}} \pm 1,44$ \\
\hline & $\mathrm{P}(0,5 \mathrm{~g})$ & $90,66^{b} \pm 1,00$ \\
\hline \multirow{5}{*}{ Eucalyptus camaldulensis } & ArNT $(0 g)$ & $98,33^{\mathbf{a}} \pm 0,88$ \\
\hline & EcD1 (24g) & $81^{\mathbf{c}} \pm 0,21$ \\
\hline & EcD2 $(30 \mathrm{~g})$ & $85^{\mathbf{c}} \pm 0,33$ \\
\hline & EcD3 (40g) & $88,33^{\mathbf{c}} \pm 1,61$ \\
\hline & $\mathrm{P}(0,5 \mathrm{~g})$ & $90,66^{\mathbf{b}} \pm 1,00$ \\
\hline \multirow{5}{*}{$\begin{array}{l}\text { Azadirachta } \\
\text { Indica }\end{array}$} & ArNT (0g) & $98,33^{\mathrm{a}} \pm 0,88$ \\
\hline & AzD1 (24g) & $79,66^{\mathbf{c}} \pm 1,99$ \\
\hline & AzD2 (30g) & $80,33^{\mathbf{c}} \pm 0,39$ \\
\hline & AzD3 (40g) & $81^{\mathbf{c}} \pm 0,61$ \\
\hline & $\mathrm{P}(0,5 \mathrm{~g})$ & $90,66^{\mathbf{b}} \pm 1,00$ \\
\hline
\end{tabular}

Remark : For the same product the averages concerning the same miniscule letter don't present any difference according to Student-Newman-Keuls' test at the level of 5\%. 
Compared effects of the germination average percentages between the vegetable powder types (Khaya. Eucalyptus and Azadirachta) according to the doses (D1, D2 and D3).

Table 2:- Compared germination of seeds from a vegetable powder type

\begin{tabular}{|l|l|l|}
\hline Vegetable powders / Witnesses & Doses $(\mathbf{g})$ & \multicolumn{1}{|c|}{ LT50 } \\
\cline { 2 - 3 } & & C. serratus Larva \\
\hline \multirow{5}{*}{ Khaya senegalensis } & ArNT $(0 \mathrm{~g})$ & $98.33^{\mathbf{a}} \pm 0.88$ \\
\cline { 2 - 3 } & KhD1 $(24 \mathrm{~g})$ & $79.33^{\mathbf{d}} \pm 0.12$ \\
\cline { 2 - 3 } & KhD2 $(30 \mathrm{~g})$ & $85^{\mathbf{c}} \pm 0.23$ \\
\cline { 2 - 3 } & KhD3 $(40 \mathrm{~g})$ & $90^{\mathbf{c}} \pm 1.44$ \\
\cline { 2 - 3 } & $\mathrm{P}(0.5 \mathrm{~g})$ & $90.66^{\mathbf{b}} \pm 1.00$ \\
\hline \multirow{5}{*}{ Eucalyptus camaldulensis } & ArNT $(0 \mathrm{~g})$ & $98.33^{\mathbf{a}} \pm 0.88$ \\
\cline { 2 - 3 } & EcD1 $(24 \mathrm{~g})$ & $81^{\mathbf{c}} \pm 0.21$ \\
\cline { 2 - 3 } & EcD2 $(30 \mathrm{~g})$ & $85^{\mathbf{c}} \pm 0.33$ \\
\cline { 2 - 3 } & EcD3 $(40 \mathrm{~g})$ & $88.33^{\mathbf{c}} \pm 1.61$ \\
\cline { 2 - 3 } & $\mathrm{P}(0.5 \mathrm{~g})$ & $90.667^{\mathbf{b}} \pm 1.00$ \\
\hline \multirow{5}{*}{ Azadirachta indica } & ArNT $(0 \mathrm{~g})$ & $98.33^{\mathbf{a}} \pm 0.88$ \\
\cline { 2 - 3 } & AzD1 $(24 \mathrm{~g})$ & $79.66^{\mathbf{c}} \pm 1.99$ \\
\cline { 2 - 3 } & AzD2 $(30 \mathrm{~g})$ & $80.33^{\mathbf{c}} \pm 0.39$ \\
\cline { 2 - 3 } & AzD3 $(40 \mathrm{~g})$ & $81^{\mathbf{c}} \pm 0.61$ \\
\cline { 2 - 3 } & $\mathrm{P}(0.5 \mathrm{~g})$ & $90.66^{\mathbf{b}} \pm 1.00$ \\
\hline
\end{tabular}

Remark : For the same product the averages concerning the same miniscule letter don't present any difference according to Student-Newman-Keuls'test at the level of 5\%.

The treated seeds of the different products (Khaya senegalensis, Eucalyptus camaldulensis, Azadirachta indica) during the bio-trials of stocking present germination percentage variations according biocide product for the Student-Newman-Keuls' test at the level of 5\%. In considering one or different plant(s) and the vegetable powder types, the non-treated witnesses ArNT $(0 \mathrm{~g}),(98.33 \% \pm 0.88)$ and chemical reference $\mathrm{P}(0.5 \mathrm{~g}),(90.66 \% \pm 1.00)$ are significantly different between them and are also significantly different to powder formulations according to doses. For the Khaya powder the germination percentages of treated seeds with KhD1 $(24 \mathrm{~g}),(79.33 \% \pm 0$. 12) present significant difference to these ones of $\mathrm{KhD} 2(30 \mathrm{~g}),(85 \% \pm 0.23)$ and $\mathrm{KhD} 3(40 \mathrm{~g}),(90 \% \pm 1.44)$. However these two last treatments don't present any significant difference in terms of seeds germination. With the Eucalyptus powder, the germination percentages of treated seeds EcD1 (24g), (81\% \pm 0.21$)$; EcD2 (30g), (85\% \pm 0.33$)$; EcD3 (40g), $(88.33 \% \pm 1.61)$ haven't any significant difference. However, these obtained percentages present significant differences to these ones of witnesses ArNT $(0 \mathrm{~g}),(98.33 \% \pm 0.88)$ and chemical reference $\mathrm{P}(0.5 \mathrm{~g}),(90.66 \% \pm 1$. 00). Considering the Azadirachta powder, the germination rates of seeds from treatments AzD1 (24g), (79. 66\% \pm 1 . 99); AzD2 (30g), $(80.33 \% \pm 0.39)$; AzD3 $(40 \mathrm{~g}),(81 \% \pm 0.61)$ don't present any significant difference. In another hand they are significantly different to the two witnesses ArNT $(0 \mathrm{~g}),(98.33 \% \pm 0.88)$ and chemical reference $\mathrm{P}$ $(0.5 \mathrm{~g}),(90.66 \% \pm 1.00)$. Except for $\mathrm{KhD} 1(24 \mathrm{~g}),(79.33 \% \pm 0.12)$, the compared effects of the germination percentages between the vegetable powder types (Khaya senegalensis, Eucalyptus camaldulensis, Azadirachta indica) according to doses (D1, D2 and D3) don't show for the Student-Newman-Keuls' test at the level of 5\% any significant difference for $\mathrm{KhD} 2(30 \mathrm{~g}),(85 \% \pm 0.23)$ and $\mathrm{KhD} 3(40 \mathrm{~g}),(90 \% \pm 1.44)$; EcD1 $(24 \mathrm{~g}),(81 \% \pm 0.21)$;

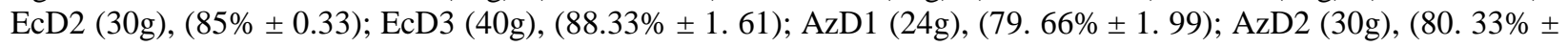
0. 39) ; AzD3 (40g), $(81 \% \pm 0.61)$.

\section{Discussion:-}

The germinal power of attacked seeds by the weevils can strongly reduce and can lead from perforated seeds of important attacks by pathogenic germs (Gain. 1897; Cruz et al.. 1988). After the insects attack, the mildews can alter, even destroy the robustness and germinal power of seeds (Cruz, 2002 ; Sembene, 2000). In this point of view our outcomes on the germination rate $79 \%$ - 98\% are clearly superior to those ones got by Lame (2011) varying from $60 \%$ to $70 \%$ for doses $(10 \mathrm{~g} / \mathrm{kg}$ and $20 \mathrm{~g} / \mathrm{kg})$ of Neem seeds powders these difference could be explained in one hand by the commonly-used proportions the plant organ but also the exhibition times LT50 much more long of 4 
stocking months. In general, when the variation of climatic conditions of the stocking area is bad controlled there would be a diminution of the germinal power (Couturon, 1980) observable from 4 stocking months. According to our experimental conditions $\left(34.21 \pm 1{ }^{\circ} \mathrm{C} ; 46.01 \pm 3 \% \mathrm{HR}\right)$ the germination of seeds from vegetable powder treatments of plants (Khaya senegalensis, Eucalyptus camaldulensis, Azadirachta indica) hasn't been affected whichever application dose during bio-trials. Except for $\mathrm{KhD} 1(24 \mathrm{~g})$, the germination rates vary from $(80.33 \% \pm 0$. $39)$ to $(88.33 \% \pm 1.61)$, respectively for the different treatments. In this stage of the discussion the essential question that we ask us is to know if these strong rates of germination could be explained by the protective activation of des different bio-actives substances of plants against the insects and mildews. Even so the passage of the powder formulation to this one of essential oils allows asserting both an efficient protection and obtained similar germination rates in the course of bio-trials.

Concerning the essential oils, taking their volatility speed in account, the duration of their persistence and the appropriate technological level for the extraction is matter in rural area for seeds protection. But if our approach remains phytopharmacological, the obtained rates with vegetable powder of the three plants are less non important than those ones got, after passage of groundnut seeds in the mechanism of Murdock and Shade (1991. 1997) by Sembene (2006). This author shows that when the solarization has occurred in cool times and/or covered. The germination rates are closed to $100 \%$ especially if the exhibition duration is brief. Unlike these rates reduce considerably in clear and hot times when the relative temperature and humidity relative increase. Inspiring of these surveys, we conclude that the heat and choice effect doses on the quality of germinal seeds are also determinant in the choice of use conditions of mechanism or biocide product if it's question of seeds. Otherwise Massala (1997) indicates that the occasioned damages by the weevils' larva on the seeds are lots of among which, alteration of seed germ (embryo), the destruction of other parts of the seed which reduces also the viability of des cotyledons (energetic socks) in addition the stain of seeds giving it unfit to human consumption (Hayma, 1985).

Actually, in the case of groundnuts destined for the consumption, we can put it in the optimal conditions of insects' destruction, otherwise these ones assuring the highest temperatures where the most toxical dose for the longest duration or exhibition times with product. In the case of seeds, it's necessary to preserve germination rates so close to $100 \%$ that possible that what is very difficult to achieve due to the presence of larva. Delobel (1993), reports that these ones after the hatching enter in the seed where they live until becoming adult. Lame (2011) reports that are what has been experimented in that concerning the diminution of germinal power by Couturon (1980) with Coffea canephora and C. stenophilla where less than $50 \%$ of viability rates have been observed from four months in fluctuant conditions against $90 \%$ in a controlled atmosphere in fifteen months of stocking. Actually, during stockadge, the seeds increase their content in water whether the surrounding isn't controlled, where the exposure necessity to the sun so as to keep the acceptable water content for the stocking (Bertenshaw. 2007). After twelve months of stocking, Smiderle and Cicero (1999) haven't observed any deterioration of physiological quality of treated maize seeds with diatom soils. With our observations where the viability of treated groundnut seeds with vegetable powders isn't influenced neither by the formulations nor the doses. That's what open alternative perspectives of witness researches of inert substances substituent the Percal 1\% or preserving them for bio-trials of confirmation as well controlled area as in real area.

\section{Conclusion:-}

The obtained outcomes of bio-trials germination of protected seeds by different vegetable powders show in general rates superior to $75 \%$. The different germination tests. reveal that the plants (Khaya senegalensis, Eucalyptus camaldulensis, Azadirachta indica) under powder forms can have a phytoinsecticide protection effect without for all that affect the germinal seeds power from this protection. However remains indicate that complementary experiences in real area would been very important for checking if phytopharmacological effect persist and the viability of seeds is preserved during log preservation stocking within the warehouses.

\section{Références bibliographiques:-}

1. Bertenshaw. V. (2007). Améliorer l'identification. la manutention et la préservation des graines à « conservation difficile » Atelier de consultation. 10-14 Juillet 2006 Ouagadougou. Burkina Faso. pp. 1-28.

2. Couturon. E. (1980). Le maintien de la viabilité des graines de caféiers par le contrôle de leur teneur en eau et de la température de stockage. Café Cacao Thé.. XXIV (1) : 27-32.

3. Cruz. R.A.. Degune. J.P.. Carburet. A.. Hekimian. C. and Ahmadi N. (2002). Lutte contre les ravageurs des cultures. Memento de l'agronomie. pp. 100-123. 
4. Cruz. J.F.. Tronde. F.. Griffon. D. and Heber. J.P. (1988). Conservation des grains en région chaudes «techniques rurale en Afrique». 2ème édition. Ministère de la coopération et du développement. Paris France. pp. 1-545.

5. Delobel. A.. and Tran. M. (1993). Les coléoptères des denrées alimentaires entreposées dans les régions chaudes. ORSTOM/CTA. Faune tropicale XXXII. pp. 1-424.

6. Diaw. S.C. (1999). Evaluation de la résistance variétale du niébé (Vigna unguiculata L.Walp.) à la bruche (Callosobruchus maculatus F). Mémoire présenté pour l'obtention du diplôme d'ingénieur agronome. pp. 1-74.

7. Gain. E. (1897). Sur la germination des grains de légumineuses habitués par les Bruches. C. R. Ac. Sc. Paris. pp. 195-197.

8. Hayma. J. (1989). Le stockage des produits agricoles tropicaux. Agrodek 3 1. ISRA/CNRA.

9. Lame. Y. (2011). Bioactivité des terres de diatomées et des poudres de neem à l'égard de bruche du niébé Callosobruchus maculatus (FAB) (Coleoptera : Bruchidae). University of Ngaoundere. pp. 1-61.

10. Larpent. J.P. (1976). La germination. In cours de Biologie et Physiologie végétales. pp. 102-108.

11. Massala. E. (1997). «Impact de la Pression de l'infestation des bruches (Callosobruchus maculatus et Caryedon serratus) sur le potentiel germinatif des graines de niébé et d'arachide : efficacité des produits végétaux pour la protection des semences ». Mémoire. CNRA. pp. 1-51.

12. Murdock. L.L. and Shade. R.E. (1991). Eradication of cowpea weevil (Coleoptera: Bruchidae) in cowpeas by solar heating. Am. Entomol.. 37 (4): 228-231.

13. Murdock. L.L.. Shade. R.E.. Kitch. L.W.. Ntourkam. G.. Lowenberg-Deboer. J.. Huesing. J.E.. Moar. W.. Chamblis. O.L.. Endondo. L. and Wolfson. J.L. (1997). Post-harvest storage of cowpea research. Copublication of IITA and JIRCAS. pp. 303-312.

14. Rao. N.K.. Hanson. J.. Dulloo. M.E.. Ghosh. K.. Nowell. D. and Larinde. M. (2006). Manuel de manipulation des semences dans les banques de gènes. Manuels pour les banques de gènes No.8. Biodiversity International. Rome. Italie. pp. 1-165.

15. Sembène. M. (2000). Variabilité de l'espaceur interne transcrit (ITS1) de l'ADN ribosomique et polymorphisme des locus microsatellites chez la bruche Caryedon serratus (Olivier) : Différenciation en race d'hôtes et infestation de l'arachide au Sénégal. Thèse de Doctorat d'Etat. Université de Dakar. pp. 1-128.

16. Sembène. M.. Gueye. M.T.. Delobel. P.. Sall. A. and Delobel. A. (2006). Désinsectisation des stocks d'arachide infestés par Caryedon serratus (OL.): utilisation de la solarisation en zone sahélienne. J. Sci.. 6 (1) : $1-11$.

17. Singh. G. and Rathod T.R. (2002). Plant growth Biomass production and soil water dynamics in a shifting dune of Indian desert. Forest Ecology and Management. 173 (3): 309-320.

18. Smiderle. O.J. and Cicero. S.M. (1999). Insecticide treatment and seed quality of corn during storage (in Portuguese with english abstract). Scientia Agricola.. 52 (1): 1245-1254.

\section{Appendices: Encodings}

ArNT: $\quad$ Untreated peanut

AzD1Tg: Azadirachta indica dose 1 Germination test

AzD2Tg: Azadirachta indica dose 2 Germination test

AzD3Tg: Azadirachta indica dose 3 Germination test

AzpD0: $\quad$ Azadirachta indica white

AzpD1: $\quad$ Azadirachta indica dose 1 treatment powder

AzpD2: $\quad$ Azadirachta indica dose 2 treatment powder

AzpD3: $\quad$ Azadirachta indica dose 3 treatment powder

AzpDR: Azadirachta indica chemical reference dose

D0: $\quad$ Dose at $0 \mathrm{~g}$ of powder. white control for bios trials 


\begin{tabular}{|c|c|}
\hline DR: & Recommended Dose \\
\hline DRP1\%: & Recommended Dose Percal 1\% \\
\hline PRSP: & Strategic Document and Poverty Reduction \\
\hline EcD1Tg: & Eucalyptus camaldulensis dose 1 Germination test \\
\hline EcD2Tg: & Eucalyptus camaldulensis dose 2 Germination test \\
\hline EcD3Tg: & Eucalyptus camaldulensis dose 3 Germination test \\
\hline EcpD0: & Eucalyptus camaldulensis white control \\
\hline EcpD1: & Eucalyptus camaldulensis dose 1 treatment powder \\
\hline EcpD2: & Eucalyptus camaldulensis dose 2 treatment powder \\
\hline EcpD3: & Eucalyptus camaldulensis dose 3 treatment powder \\
\hline EcpDR: & Eucalyptus camaldulensis chemical reference dose \\
\hline KhD1Tg: & Khaya senegalensis dose 1 Germination test \\
\hline KhD2Tg: & Khaya senegalensis dose 2 Germination test \\
\hline KhD3Tg: & Khaya senegalensis dose 3 Germination test \\
\hline KhpD0: & Khaya senegalensis white control \\
\hline KhpD1: & Khaya senegalensis dose 1 treatment powder \\
\hline KhpD2: & Khaya senegalensis dose 2 treatment powder \\
\hline KhpD3: & Khaya senegalensis dose 3 treatment powder \\
\hline KhpDR: & Khaya senegalensis chemical reference dose \\
\hline P1: & Percal repetition 1 \\
\hline P2: & Percal repetition 2 \\
\hline P3: & Percal repetition 3 \\
\hline PTg: & Percal 1\% Germination Test \\
\hline TB: & White witnesses \\
\hline Tg: & Germination test \\
\hline TN: & Untreated control \\
\hline
\end{tabular}

